\title{
ASSESSMENT OF FIREFIGHTERS-RESCUERS' WORK SEVERITY IN RELATION WITH INTERACTION BETWEEN PHYSICAL AND MENTAL LOAD
}

\author{
Ženija Roja*, Valdis Kaḷ̦is*, Henrijs Kaḷ̣is*, and IImārs Pencis** \\ * Faculty of Chemistry, University of Latvia, Krišjāṇa Valdemāra iela 48, Rīga, LV-1013, LATVIA \\ ${ }^{* *}$ Faculty of Engineering Economics and Management, Rīga Technical University, Meža iela 48, Rīga, LV-1048, LATVIA
}

Communicated by Andris Zicmanis

\begin{abstract}
The present work is focused on occupational health problems caused by ergonomic risk in firefighting, which is one of the most hazardous occupations. The aim was to evaluate the work heaviness degree and to estimate the muscle fatigue for a study group consisting of 12 firefighters-rescuers. Applying qualitative ergonomic analyses (OWAS a.o.) and clinical experiments to determine consumed metabolic energy using heart rate monitoring, the following work hardness categories were observed: firefighter-rescuer - category III (hard work, $8.2 \pm 1.2$ $\mathrm{kcal} / \mathrm{min}$ ); commanding officers - category II (moderate work, $6.0 \pm 1.6 \mathrm{kcal} / \mathrm{min})$. Assessment of muscle strain and functional state (tone) using myotonometric measurements showed several muscle tone levels, allowing subdivision of firefighters into different conditional categories basing on muscle tone and fatigue: I - a state of equilibrium when muscles are able to adapt to the work load and are partly able to relax; and II - muscle fatigue and increased tone. It was also found that the increase of muscle tone and fatigue mainly depended on workers physical preparedness and length of service, and less on their age. Assessment interaction of mental and physical load using NASA-TLX method indicated that the highest degree of total workload was for several firemen, especially, commanding officers when temporary demands, task performance, effort and frustration were taken into consideration.
\end{abstract}

Key words: firefighters, physical and mental load, myotonometry, heart rate, muscles fatigue.

\section{INTRODUCTION}

It is well known that muscle and skeletal system disorders caused by work are widespread diseases in most of the world countries. The number of occupational diseases caused by work overload is growing rapidly also in the European Union country Latvia and this can be referred also to firefighters who have to work very intensively, especially in extreme situations when they are working as rescuers. They work in forced/constrained work postures and are overstrained during the work in specific parts of their bodies. Firefighters-rescuers face also high psychological demand in operative tasks; therefore, they are subjected to interaction of physical and mental work. The aim of this study was to evaluate the work heaviness degree and to estimate the muscle fatigue of firefighters-rescuers during a six-week period. For the study, firefighters-rescuers were selected according to the following criteria: no acute musculoskeletal symptoms and full consent to participate in clinical measurements.

\section{MATERIALS AND METHODS}

Study design. The object of the research was firemenrescuers, who were working in a team (group). Employees who participate in fire fighting and rescue work can be subdivided into several representative categories: firefighters, firefighters-engine drivers and commanding officers. The all-male study group consisted of 12 firefighters aged between 18 and 50 years, length of service between 5 and 20 years. All of the firefighters were right-handed. Background factors of the subjects are shown in Table 1.

Methods. To quantify firefighter metabolic energy consumption, when a heavy object (fire-hose a.o.) in different work phases is being moved, the formula of Goldman and Givoni was used (Givoni and Goldman, 1971):

$$
\mathrm{MEC}=\mathrm{n} \times(\mathrm{W}+\mathrm{F}) \times\left\{2.3+0.32(\mathrm{~V}-2.5)^{1.65}+\mathrm{G} \times\right.
$$$$
\times[0.2+0.07(\mathrm{VV}-25)]\},
$$

where: MEC - metabolic energy consumption, $\mathrm{W} ; \mathrm{n}$ - environmental factor (on flat surface $\mathrm{n}=1$ ); $\mathrm{W}$ - weight of the 
BACKGROUND FACTORS OF THE SUBJECTS, MEAN, STANDARD DEVIATION (SD) AND RANGE

\begin{tabular}{l|c|c|c|c}
\hline \multirow{1}{*}{ Variable } & \multicolumn{2}{c|}{$\begin{array}{c}\text { Firefighters-rescuers } \\
(\mathrm{n}=9)\end{array}$} & \multicolumn{2}{c}{$\begin{array}{c}\text { Comanding officers } \\
(\mathrm{n}=3)\end{array}$} \\
\cline { 2 - 5 } & mean $\pm \mathrm{SD}$ & range & mean \pm SD & range \\
\hline Age (years) & $34 \pm 4$ & $18-50$ & $30 \pm 4$ & $30-40$ \\
Height $(\mathrm{cm})$ & $180 \pm 5$ & $173-187$ & $172 \pm 7$ & $165-180$ \\
Weight $(\mathrm{kg})$ & $80 \pm 9$ & $65-97$ & $76 \pm 6$ & $60-92$ \\
$\begin{array}{l}\text { Body mass index } \\
\text { (BMI, kg/m }{ }^{2} \text { ) }\end{array}$ & $25 \pm 6$ & $17-36$ & $25 \pm 3$ & $19-28$ \\
$\begin{array}{l}\text { Rest heart rate } \\
\text { (beats/min) }\end{array}$ & $67 \pm 7$ & $56-78$ & $62 \pm 6$ & $50-74$
\end{tabular}

worker, kg; F - load, kg; V - walking speed, km/h; G - gradient, $\%$.

The work heaviness degree depending on workers' physical activity (intensity) was estimated by heart rate monitoring (HRM) using a POLAR S810i device, which sums up the acquired HRM data and transforms it into energy expenditure $(\mathrm{kcal} / \mathrm{min})$. HRM data correlates with oxygen consumption and allows quantifying the objective energy expenditure for each work phase including rest periods (Jackson et al., 1990). Work heaviness in terms of $\mathrm{kcal} / \mathrm{min}$ was classified according to the scale shown in Table 2.

Table 2

WORK HEAVINESS CLASSIFICATION IN TERMS OF ENERGY EXPENDITURE

\begin{tabular}{lc|c}
\hline \multicolumn{2}{c|}{$\begin{array}{c}\text { Workload categories } \\
\text { NIOSH (USA) standard, } \\
\text { ISO 28996 }\end{array}$} & $\begin{array}{c}\text { Energy expenditure* } \\
\text { Male, } \\
\mathrm{kcal} / \mathrm{min}\end{array}$ \\
\hline Light work & I & $2.0-4.9$ \\
Moderate work & II & $5.0-7.4$ \\
Hard work & III & $7.5-9.9$ \\
Very hard work & IV & $10.0-12.4$ \\
Ultimate work & V & more than 12.5
\end{tabular}

* Energy expenditure transformed: $1 \mathrm{~W}=1 \mathrm{~J} / \mathrm{s}=0.0143 \mathrm{kcal} / \mathrm{min}$.

The work postures and work task heaviness were analysed simultaneously with HRM from still videotape frames every $30 \mathrm{~s}$ for each work task (phases) with the OWAS (Ovako Working Posture Analysis System) method using WinOWAS software (Louhevaara and Suurnäkki, 1992). Using this method compulsive working postures were identified and necessary alterations were determined according to OWAS action categories (AC): 1 = normal postures, no action required; 2 = the posture is slightly harmful, actions to alter postures should be taken in the near future; $3=$ the posture is distinctly harmful, actions to alter postures should be taken as soon as possible; $4=$ the posture is extremely harmful, actions to correct postures should be taken immediately.

Assessment of the functional state of skeletal muscle (including determination of muscles fatigue) was carried out using myotonometric (MYO) measurements with the MYOTON-3 device (Vain and Kums, 2002), which allows measuring muscle contraction frequency $(\mathrm{Hz})$ and stiffness $(\mathrm{N} / \mathrm{m})$. The principle of the MYO lies in using an acceleration probe to record the reaction of the peripheral skeletal muscle or its part to mechanical impact (the force of the impact does not create changes in the biological tissue or precipitate neurological reactions) and the subsequent analysis of the resulting signal with the aid of the personal computer (Roja et al., 2006). The testing end (mass 20 grams) of the computerised MYO device was in contact with the muscle belly area (see Fig. 1) and the effective weight was employed on the surface of the measuring tissue. The device was fired in response to a fixed posture at the testing sensor end.

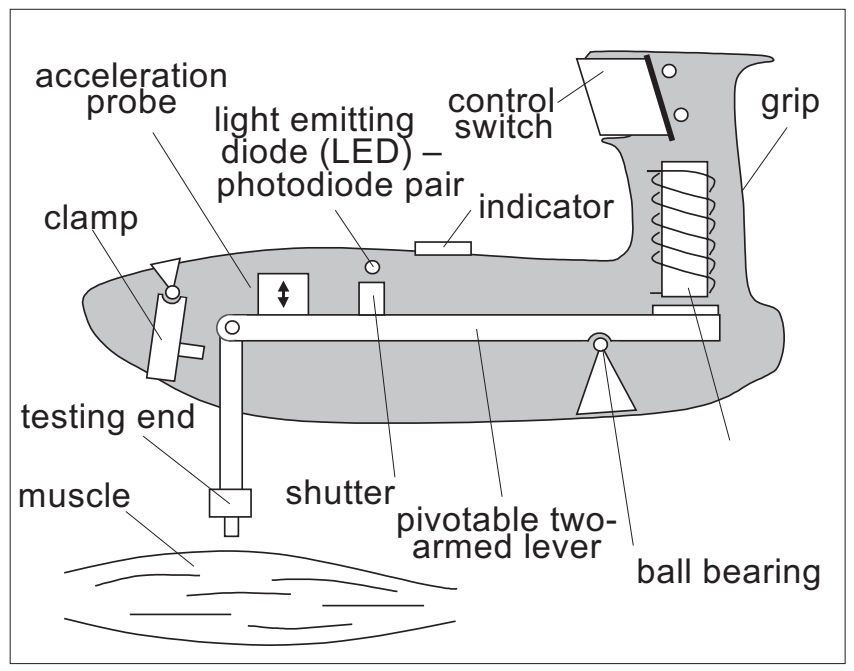

Fig. 1. Schematic drawing of a myotonometer.

MYO testing of the following muscles was performed in relaxed state: $m$. extensor digitorum; $m$. flexor carpi radialis; $m$. gastrocnemius (caput mediale); $m$. tibilais anterior and $m$. trapezius (upper part). The procedure of muscle testing was performed in sitting position, on a chair; the muscle length was middle; for all measurements, the subject took the same position. Measurements for determination of muscle tone during six weeks were made every Monday with relaxed muscles before the work cycle had started. In this way, the most precise results can be obtained when estimating muscle fatigue or the ability to restore elastic muscle qualities after the work cycle.

Interaction of mental and physical load was determined using NASA-TLX (National Aeronautics and Space Administration - Task Load Index) software (Hart and Staveland, 1998). NASA-TLX is a multi-dimensional rating procedure that derives an overall workload score based on a weighted average of ratings on six subscales (Fig. 2a). These subscales include: Mental Demands (How mentally demanding was the task?), Physical Demands (How physically demanding was the task?), Temporal Demands (How hurried or rushed was the pace of the task?), Own Performance (How successful were you in accomplishing what 
a

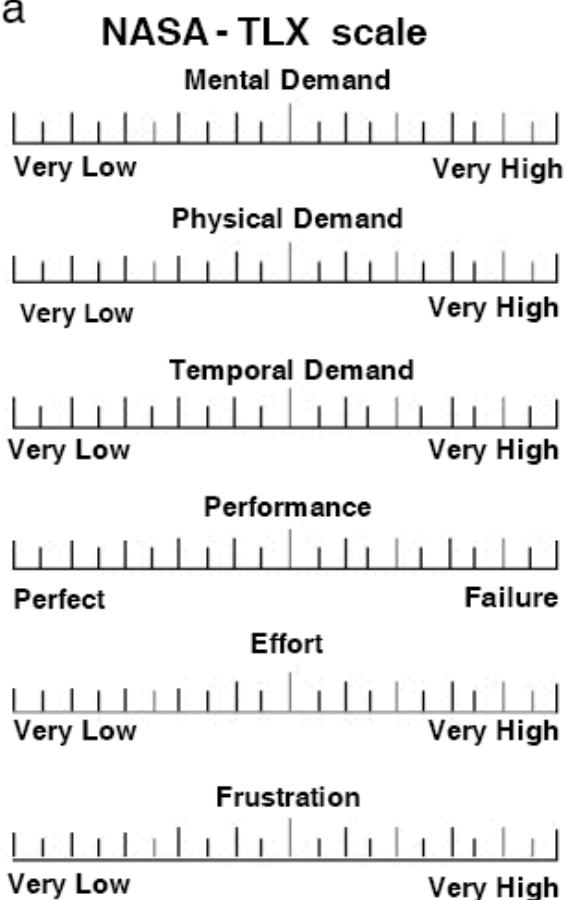

b

\begin{tabular}{|c|c|c|c|c|c|}
\hline & \multicolumn{5}{|c|}{$\begin{array}{l}\text { Recalculation Tabl e } \\
\text { (priority of the load) }\end{array}$} \\
\hline 1 & Mental & O] & or & Physical & $D$ \\
\hline 2 & Mental & $D$ & or & Effort & 0 \\
\hline 3 & Physical & Ol] & or & Frustration & O \\
\hline 4 & Physical & $\mathrm{Ol}$ & or & Performance & $\mathrm{O}$ \\
\hline 5 & Physical & OII & or & Temporal & 0 \\
\hline 6 & Frustration & 0 & or & Mental & 0 \\
\hline 7 & Frustration & OाI & or & Effort & 0 \\
\hline 8 & Performance & 0 & or & Mental & 0 \\
\hline 9 & Performance & 0 & or & Frustration & 0 \\
\hline 10 & Performance & 0 & or & Temporal & 0 \\
\hline 11 & Effort & Oा & or & Physical & 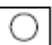 \\
\hline 12 & Effort & O] & or & Performance & 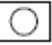 \\
\hline 13 & Temporal & 0 & or & Frustration & ᄀ \\
\hline 14 & Temporal & Oll & or & Mental & 0 \\
\hline 15 & Temporal & 0 & or & Effort & \\
\hline
\end{tabular}

Fig. 2. NASA-TLX subscales (a) and Table of recalculation steps (b). you were asked to do?), Effort (How hard did you have to work to accomplish your level of performance?), and Frustration (How insecure, discouraged, irritated, stressed, and annoyed were you?).

The six different subscales are divided into 20 steps which are recalculated using NASA-TLX software to a scale of 1 to 100 points. Recalculation steps (in all 15) show the interaction between definitions of six subscales determining the priorities of each factor (see Fig. 2b). The ratings are then weighted to a total score and recalculated to a mean value, so that the results can be compared. The recalculation steps make NASA-TLX very sensitive to different levels of workload. Since it is a multidimensional method, it can be used to diagnose what it is that creates workload (may be a combination of factors) and to identify opportunities and ways to reduce the workload of situations when it has become too heavy.

The reliability of the statistical processing of heart rate monitoring and myotonometry data was determined using correlation analysis (Pearson's correlation coefficient $r$, a.o.), the reliability interval (interrater agreement) was also calculated by determining the Cohen's Kappa coefficient $(\kappa)$, which identifies connectivity of the experimental data,

the number of participants and the participants' acceptance proportion or correlation of the experimental data (Landis and Koch, 1977).

\section{RESULTS}

To evaluate the work heaviness degree in terms of energy expenditure the following tasks with 1-hour-long work period were chosen: task 1 - fire-drill (walking and carrying, climbing, ascending stairs, hammering, hose rolling): task 2 - objective fire cancellation work (fire caused by burning of a small farm). Each task included different working phases which where investigated using OWAS analysis and HRM.

Research results of HRM and OWAS for fire-drill task are summed up in Table 3. HRM was calculated as mean heart rate and energy expenditure of each person, standard deviation (SD), Pearson's correlation ( $r$, and Cohen's Kappa coefficient $(\kappa)$ are given. A typical HRM computer based diagram for firefighter is reflected in Figure 3.

Although the work heaviness degree was identified, this does not show the objective fatigue of muscles. Therefore, a

Table 3

CALCULATED ENERGY EXPENDITURE ( $\left.\mathrm{E}_{\text {math }}\right)$, FIREFIGHTERS' HEART RATE (HR), PEARSON'S CORRELATION (r), COHEN'S KAPPA ( $\kappa$ ), OBJECTIVE ENERGY EXPENDITURE FROM HRM DATA (E), WORK HEAVINESS CATEGORY (WHC), AND OWAS ACTION CATEGORY (AC)

\begin{tabular}{|c|c|c|c|c|c|c|c|c|}
\hline \multirow[t]{2}{*}{ Occupation } & \multirow{2}{*}{$\begin{array}{c}\mathrm{E}_{\mathrm{math}} \pm \mathrm{SD} \\
\mathrm{kcal} / \mathrm{min}\end{array}$} & \multicolumn{4}{|c|}{ Heart rate monitoring data } & \multirow{2}{*}{$\begin{array}{c}\text { Objective } \\
\mathrm{E} \pm \mathrm{SD} \\
\mathrm{kcal} / \mathrm{min}\end{array}$} & \multirow[t]{2}{*}{ WHC } & \multirow[t]{2}{*}{$\mathrm{AC}$} \\
\hline & & $\begin{array}{c}\text { mean } \\
\mathrm{HR} \pm \mathrm{SD}, \\
\text { beats } / \mathrm{min}\end{array}$ & $\begin{array}{l}\text { range } \mathrm{HR} \text {, } \\
\text { beats/min }\end{array}$ & $r$ & $\kappa$ & & & \\
\hline Firefighters $(n=7)$ & $7.2 \pm 0.5$ & $150 \pm 13$ & $140 \ldots 185$ & 0.95 & 0.75 & $8.4 \pm 1.1$ & III & 4 \\
\hline Firefighters (fire-engine driver) $(\mathrm{n}=2)$ & $6.0 \pm 0.5$ & $138 \pm 14$ & $132 \ldots 170$ & 0.95 & 0.68 & $8.1 \pm 1.5$ & III & 2 \\
\hline Commanding officers $(n=3)$ & $5.5 \pm 0.5$ & $130 \pm 16$ & $120 \ldots 160$ & 0.95 & 0.82 & $6.0 \pm 1.6$ & II & 1 \\
\hline
\end{tabular}




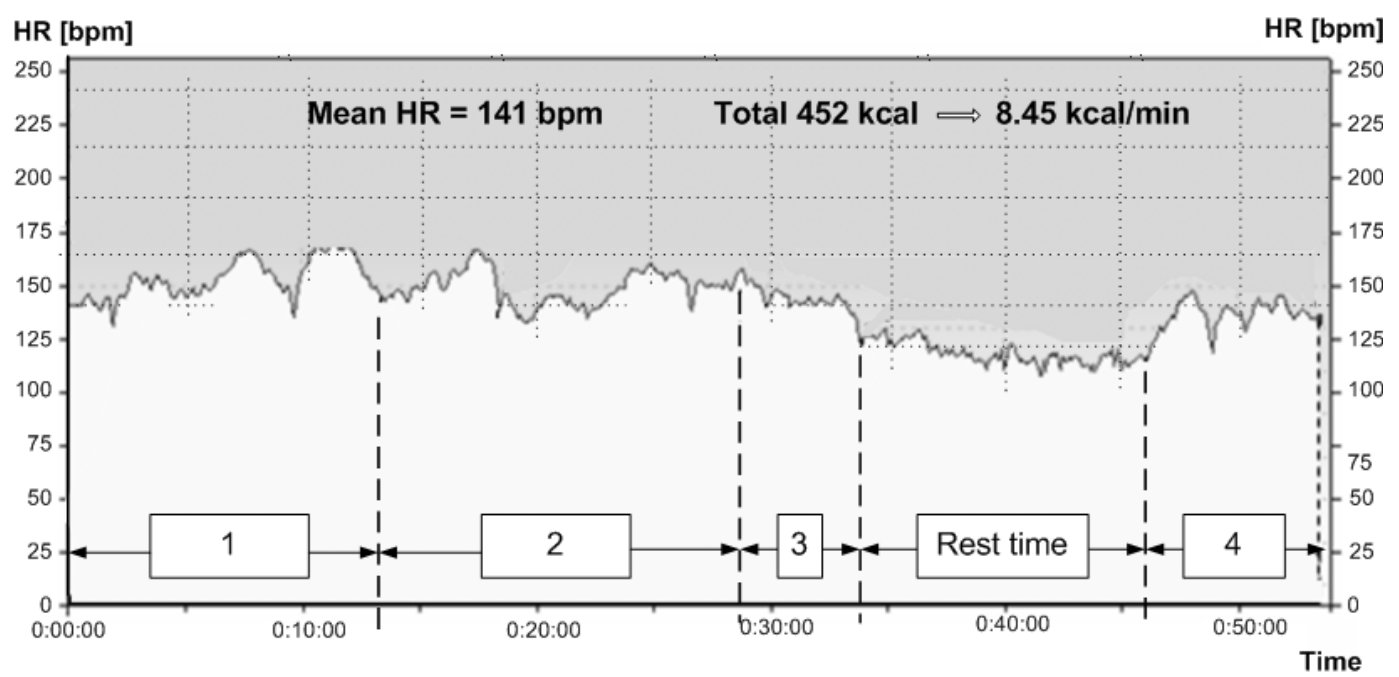

Fig. 3. Typical HRM diagram for a firefighter (age 25 years, $\mathrm{HR}_{\text {rest }}=70$ beats $/ \mathrm{min}$; $\mathrm{HR}_{\max }=170$ beats $/ \mathrm{min}$; $\mathrm{HR}_{\text {mean }}=141$ beats $\left./ \mathrm{min}\right)$. Working operations (total 55 $\min ): 1$ - extracting trunk fire hose; 2 - turning on firefighting respirator (FR) and working with hose shank; 3 removing FR, suspending fire cancelling and comeback to starting point; 4 - collection of fire hose.
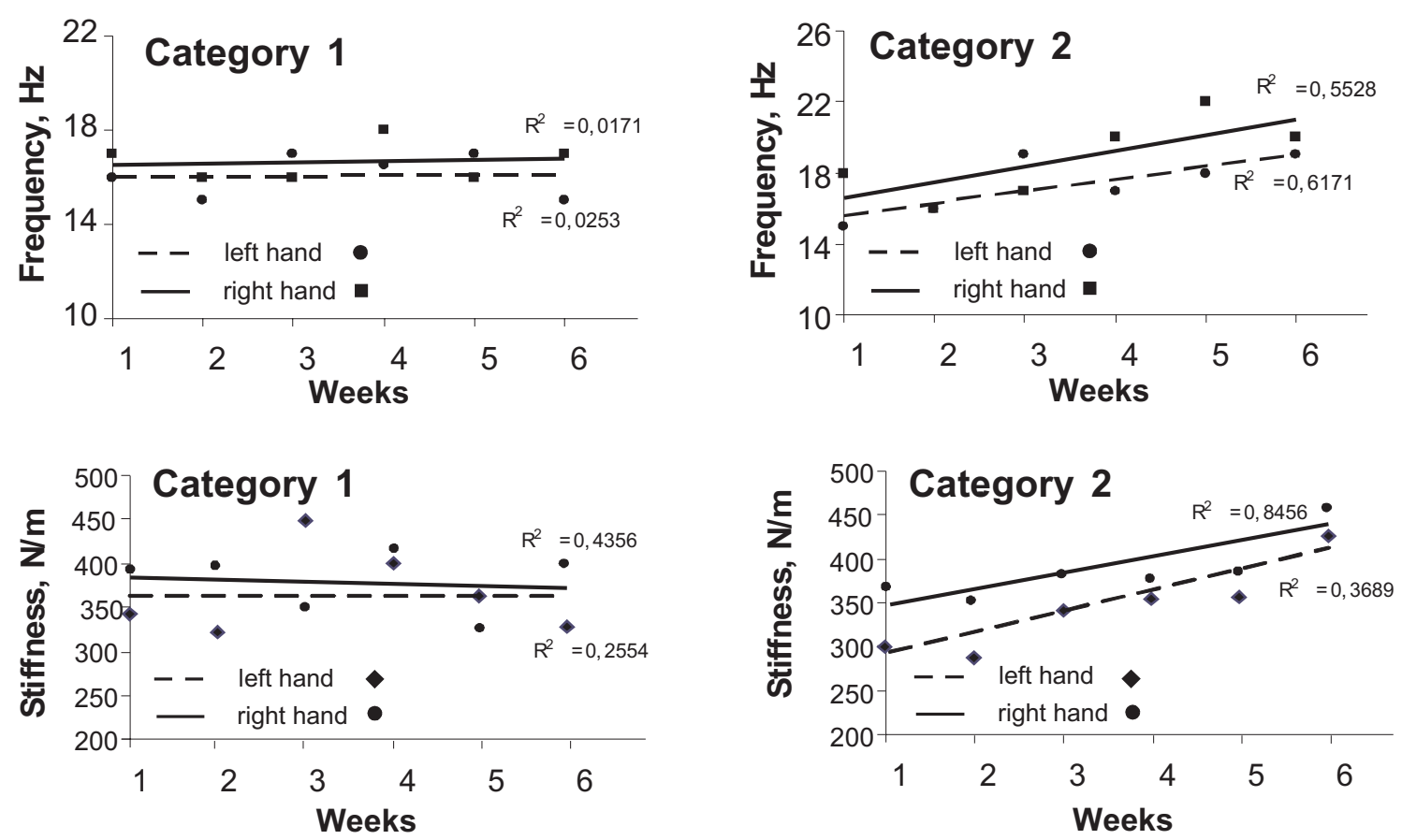

Fig. 4. Results of the regression analysis of m. extensor digitorum frequency and stiffness during consecutive 6 work weeks and myotonometric categories.

further research work was carried out using MYO measurements were used. According to regression analysis of MYO data, several muscle tone levels were identified allowing subdivision of firefighters into different conditional categories basing on muscle tone and fatigue: I - a state of equilibrium, when muscles are able to adapt to the work load and are partly able to relax (no significant changes, muscles frequency and stiffness do not exceed the norm); and II muscle fatigue and increased tone (frequency and stiffness exceeds the norm).

An example of MYO measurement data is reflected in Figure 4. It was determined that the increase of muscle tone and fatigue mainly depends on worker physical skill and length of service (Table 4).

Comparative data showing the load of separate muscle groups for firefighters who are not to be able to adapt to the
Table 4

PER CENT OF FIREFIGHTERS $(\mathrm{n}=12)$ WITH DIFFERENCES IN THEIR MUSCLE TONE (CATEGORIES I AND II) DEPENDING ON THE LENGTH OF OCCUPATIONAL SERVICE

\begin{tabular}{c|c|c|c|c|c}
\hline \multicolumn{6}{c}{ Length of service in the occupation, years } \\
\hline \multicolumn{3}{|c|}{$5-10$} & $\kappa$ & \multicolumn{3}{c}{$>10$} \\
\hline category & $r$ & category & $r$ & \\
\hline I $-80 \%$ & 0.68 & 0.80 & I $-50 \%$ & 0.68 & 0.70 \\
II $-20 \%$ & 0.68 & 0.65 & II $-50 \%$ & 0.68 & 0.45
\end{tabular}

workload (MYO category II) is reflected in Figure 5. The results show the average value of muscle frequency, i.e. changes in the muscle tone in the beginning and at the end of investigation (after six weeks).

In our investigation, combined physical and mental workload was estimated experimentally using HRM, which gives 


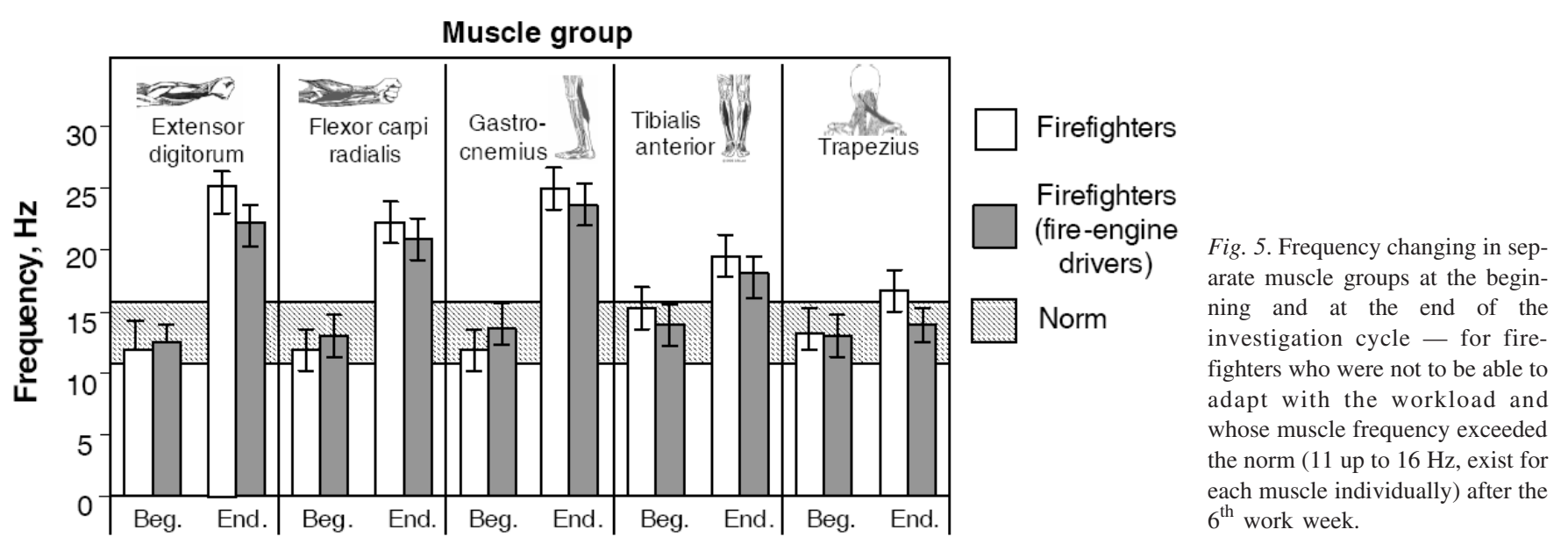

Table 5

CHARACTER OF MENTAL AND PHYSICAL LOAD ACCORDING TO THE NASA-TLX VALUE SCALE

\begin{tabular}{l|c|c|c|c}
\hline \multirow{1}{*}{ Factors } & \multicolumn{2}{c|}{$\begin{array}{c}\text { Commanding officers } \\
(\mathrm{n}=3)\end{array}$} & \multicolumn{2}{c}{$\begin{array}{c}\text { Firefighters } \\
(\mathrm{n}=9)\end{array}$} \\
\cline { 2 - 5 } & score & $\begin{array}{c}\text { significance, } \\
\%\end{array}$ & score & $\begin{array}{c}\text { significance, } \\
\%\end{array}$ \\
\hline Mental demand & $70 \pm 2$ & 20 & $29 \pm 2$ & 11 \\
Physical demand & $45 \pm 2$ & 9 & $74 \pm 2$ & 30 \\
Temporal demand & $77 \pm 2$ & 32 & $65 \pm 2$ & 26 \\
Performance & $33 \pm 2$ & 18 & $24 \pm 2$ & 9 \\
Effort & $67 \pm 2$ & 18 & $66 \pm 2$ & 17 \\
Frustration & $32 \pm 2$ & 3 & $35 \pm 2$ & 7 \\
Total workload & $\mathbf{6 5} \pm \mathbf{2}$ & $100 \%$ & $\mathbf{5 8} \pm \mathbf{2}$ & $100 \%$
\end{tabular}

the actual workload category from energy expenditure data. The interaction of a mental and physical load using NASA-TLX software allowed to estimate the total workload and compare the significance in per cent (see Table 5) of different demands according to the value scale offering by software.

A typical computer-based NASA-TLX analysis diagrams (for one firefighter and one commander) are shown in Figure 6 where significance as per cent from recalculation data is shown as weight score points. The obtained results showed the importance of influence of the above mentioned factors and total workload. All results are based on firefighter-rescuer observation and questionnaire data at the end of the investigation (after six work weeks).

\section{DISCUSSION}

The ergonomic analysis confirmed the work hardness categories, accordingly to NIOSH standards they vary from category II (moderate work) for officers to category III (hard work) for firefighter-rescuers. Therefore, in total firefighters-rescuers (firefighters and firefighters-engine drivers) work should be considered as moderately hard work according to average metabolic energy consumption up to $6-7 \mathrm{kcal} / \mathrm{min}$. Comparing the data determined experimentally with that calculated it can be concluded that the actual energy expenditure is about $11.6 \%$ higher and reaches $8 \mathrm{kcal} / \mathrm{min}$. This possibly means that the calculations did not take into account when firefighter climbs the stairs and other factors activities.

The results obtained from actual fire fighting work on a small farm showed decreased energy expenditure values: for firefighters $-7.0 \pm 1.5 \mathrm{kcal} / \mathrm{min}$, and for commanding officers $-4.0 \pm 1.5 \mathrm{kcal} / \mathrm{min}$. It means that actually in this case all firefighters' occupations fall within category II moderate work, although in other cases this workload can be comparable with training load (sometimes even greater) if the burning object is very huge or firefighters operate in the extreme situations when they are working as rescuers.

Determining the heart rate differences for firefighters divided into two age groups (18-35 and 36-50 years), for the elderly group the heart rate increased, but not significantly. Average energy expenditure increased approximately $1.8 \pm$ $1.1 \mathrm{kcal} / \mathrm{min}$, therefore, increasing the work heaviness category, but not achieving category IV — very hard work
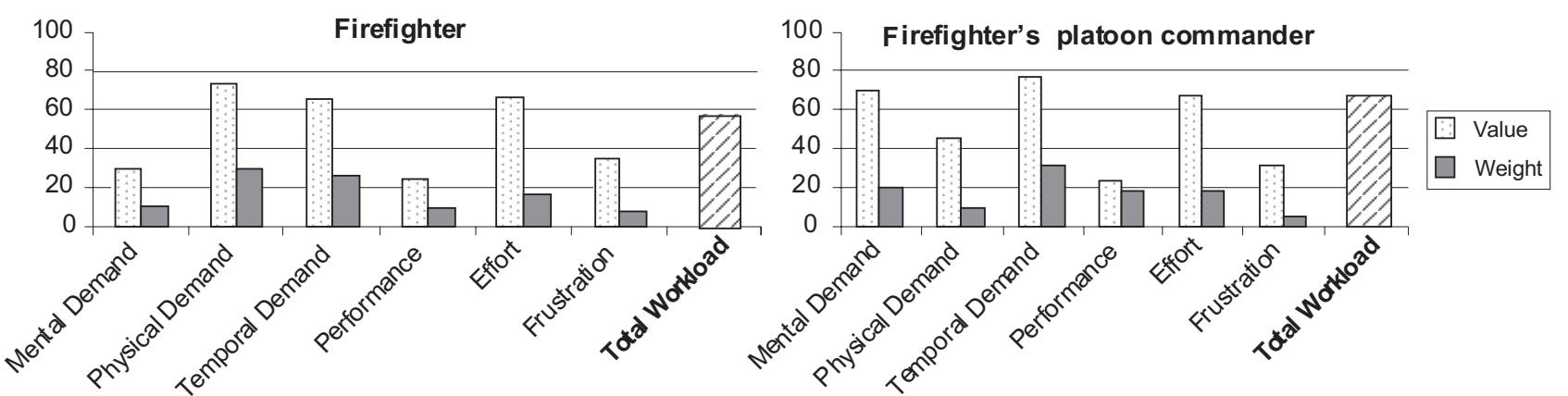

Fig. 6. Example of NASA-TLX physical and mental workload interaction diagram for firefighter and firefighter platoon commander. 
(> $10 \mathrm{kcal} / \mathrm{min}$ ). For this reason, when considering work organisation, attention has to be paid to the factors that make the work more difficult (e.g. high scaffolds, great distances to move heavy loads and a.o.).

Firefighter fitness and muscle mass as well as load and fatigue of individual muscles in this calculation were not considered; these parameters were analysed separately by MYO investigation. Analysis of the MYO data shows that for the firefighters the greatest load was put on arm muscles ( $m$. extensor digitorum and $m$. flexor carpi radialis) and leg muscles, especially on $m$. gastrocnemius. The reason for this is that firefighter work usually involves fast arm movements using hoses, fire hooks and crowbars, and the load on the shoulder line is relatively insignificant.

As shown in Figure 3, firefighter-driver work practically does not differ from firefighter work because they also take part into several fire fighting work phases. It was determined that the normal frequency of muscles was exceeded by 60 per cent in all kinds of investigated firefighter occupations, the stiffness by 70 per cent after six weeks of intensive fire-drill and actual fire fighting work. This can be explained by insufficient rest breaks throughout the training period and fire work.

MYO data also shows that muscles that are located in different sides of the body are adapted to work load differently. This was found for both firefighters and firefightersdrivers. There were some firefighters working with both arms equally, for some others the left arm was involved more than the right. However, this does not mean that these workers were left-handed; the reason for this is the specificity of the performed activity, namely, the weight of a material in order to remove obstruction and other barriers, which has to be carried on the hooks or crowbars, held by the right or left arm.

We have relatively little information on assessment of combined physical and mental workload, especially, which would be applicable to a particular profession. One of the reasons why there is a lack of such information could be that there are no models explaining connection between attention required by the work and performance of the work to be done. Almost all existing methods are related to individual spheres, with the central idea that oxygen consumption may help us to assess both physical and mental components of the workload (Mital and Goviadaraj, 1999). Therefore, when the level of mental workload (including stress caused by temporal demand or frustration) also increases the heart rate, blood pressure goes up and increases contraction ability of heart muscles that in turn increases oxygen consumption.

The results of NASA-TLX analysis show that highest degree of total workload considering mental and physical load interaction was identified for firefighter commanding officers: 65 value points. In comparison, firefighters-rescuers only reached 58 value points. This is because commanding officers also actively participated in fire-fighting work that included simultaneously physical exercise and considerable mental stress (temporary demands, task performance as well as effort and frustration were taken into consideration).

In case of firefighters, mental load is more related to psycho-emotional load and less to processes like decisionmaking and solution finding. Physical performance is not significantly influenced when stress is not taken into account. Work stress, including a temporal factor, related only to tension due to a limited time to perform tasks, is, however, high enough resulting in 64 points with a comparatively great significance -26 per cent (for commanding officers 32 per cent). Frustration level (how insecure, uncertain the employees feel, with how great enthusiasm they perform their tasks) of firefighters is relatively great 7 points, less for commanders ( 3 points). Therefore, mental load significantly influences physical load, changing the significance of various subscales factors in the NASA-TLX assessment scale.

The necessary preventive activities to reduce the heavy workload can be achieved by improving work organisation as well as worker health and wellbeing. Our recommendations are: firefighters should be allowed to select most appropriate work methods individually; appropriate time for rest breaks for individuals according to determined work heaviness category, for example, persons that have III work heaviness category rest breaks at least 5 till 7 minutes long are recommended after each hour of intensive working time; the early multidisciplinary rehabilitation (relief exercises, behaviour therapy a.o.) could significantly improve workers health who suffer from chronic and subacute muscular skeletal pain caused by heavy workload.

In conclusion, the present results show that despite rapid technical improvements, firefighters work still requires hard manual activities, compulsive working postures and constantly repeated arm movements, which result in fatigue and changes in muscle tone. For that reason firefighters-rescuers can be subdivided into hard and moderately hard work categories based on the complex analysis consisting of the heart rate monitoring and the assessment of compulsive working postures, and can be subdivided into the two categories basing on myotonometrisc investigations. It was found that mental load influences significantly physical load changing in significance of various subscales factors in NASA-TLX assessment scale and this has to be carefully considered when assessing work ability. The method used can provide prognosis of occupational pathology or work-related musculoskeletal disorders under different workload conditions.

\section{REFERENCES}

Givoni, B., Goldman, R. (1971). Predicting metabolic energy cost. J. Appl. Physiol., 30, 429-433.

Hart, S.G., Staveland, L.E. (1988). Development of NASA-TLX (Task Load Index): Results of empirical and theoretical research. In: Hancock, A. and Meshkati, N. (eds.). Human mental workload (pp. 139-183). Amsterdam: North-Holland. 
Jackson, A.S., Blair, S.N., Mahar, M.T., Wier, L.T., Ross, R.M. (1990). Stuteville JE: Prediction of functional aerobic capacity without exercise testing. Med. Sci. Sports Exercise, 22, 863-870.

Landis, J.R., Koch, G.G. (1977). The Measurement of Observer Agreement for Categorical Data. Biometrics, 33, 159-174.

Louhevaara, V., Suurnäkki, T. (1992). OWAS: Training Publication II. Finish Institute for Occupational Health, Helsinki. 102 pp.

Received 2 January 2009
Mantoe, H.I., Kemper, W.M., Saris, M., Washburn, R.A. (1996). Measuring Physical Activity and Energy Expenditure. Human Kinetics Publishers, Champaign, Illinois, USA. 200 pp.

Mital, A. and Goviadaraj, M. (1999). Is it possible to have a single measure for all work? Int. J. Industr. Ergon., 6(3), 190-195.

Roja, Z., Kalkis, V., Eglite, M., Vain, A., Kalkis, H. (2006). Assessment of skeletal muscles fatigue of road maintenance workers based on heart rate monitoring and myotonometry. J. Occup. Med. Toxicol., 1, 20-28.

Vain, A., Kums, T. (2002). Criteria for Preventing Overtraining of the Musculoskeletal System of Gymnasts. Biol. Sport, 19(4), 329-345.

\section{UGUNSDZĒSĒJU - GLĀBĒJU DARBA SMAGUMA NOVĒRTĒŠANA SAISTĪBĀ AR FIZISKĀS UN GARĪGĀS SLODZES MIJIEDARBĪBU}

Šajā darbā pētītas ugunsdzēēēju - glābēju arodveselības problēmas saistībā ar ergonomiskiem riskiem. Pētījuma mērḳis bija noteikt darba smaguma pakāpi un novērtēt muskuḷu nogurumu fiziskā un garīgā darba mijiedarbības rezultātā 12 ugunsdzēsējiem, kuri strādā vienā komandā. Pētījumā lietotas kvalitatīvāss ergonomiskās analīzes metodes (OWAS u.c.) un veikti klīniskie pētījumi: sirds ritma monitorings, lai izvērtētu darba procesā patērēto metabolisko enerǵiju, un miotonometrisko mērījumu analīze, lai noteiktu muskuḷu tonusu un izvērtētu to noguruma pakāpi. Pēc sirdsdarbības ritma monitoringa datiem noteiktas vairākas darba smaguma kategorijas: ugunsdzēsējiem - glābējiem III kategorija (smags darbs, 8,2 $\pm 1,2 \mathrm{kcal} / \mathrm{min}$ ); ugunsdzēsēju komandieriem - II kategorija (vidēji smags darbs, 6,0 $\pm 1,6 \mathrm{kcal} / \mathrm{min}$ ). Analizējot muskuḷu spriedzi un to funkcionālo stāvokli (tonusu), lietojot miotonometrijas metodi, noteiktas šādas muskuḷu tonusa un noguruma kategorijas: I - līdzsvara stāvoklis, kad muskuḷi spēj pielāgoties darba slodzei un dạ̣ēji spēj relaksēties; II - norāda uz muskuḷu nogurumu un palielinātu tonusu. Pētījumi parādīja, ka muskuḷu tonusa un noguruma pakāpe ir atkarīga no darbinieku fiziskās sagatavotības. To ietekmē arī darbinieku vecums. Novērtējot garīgā un fiziskā darba mijiedarbību ar ASV Nacionālā aeronautikas un kosmosa administrācijā izstrādāto metodi NASA-TLX, noteikts, ka kopējā darba slodze ugunsdzēsēju komandieriem ir lielāka nekā ugunsdzēsējiem un ugunsdzēěanas mašīnu vadītājiem, jo tā tiek analizēta ar speciālas datorprogrammas palīdzību, ievērojot vairāku citu faktoru (laika ierobežojums uzdevumu izpildei, izpildījuma kvalitāte, frustrācija jeb nepārliecinātība par veiktā uzdevuma kvalitāti u.c.) multidimensionālo ietekmi. 